\title{
Review: Modification of Nanocellulose as Conjugate of infection- causing Antibacterial Hydrogel
}

\author{
Anisa, Metik Ambarwati, Anggi Ayunda Triani, Indra Lasmana Tarigan*
}

Program Studi Kimia, Faculty of Sciences and Technology, Universitas Jambi, Indonesia

\begin{tabular}{l} 
I N F O A R T I K E L \\
\hline Diterima 06 Februari 2021 \\
Disetujui 30 April 2021 \\
\hline Key word: \\
Infeksi \\
Antibakteri \\
Nanoselulosa \\
Hydrogel \\
\hline Kata kunci: \\
Infection \\
Antibacterial \\
Nanocellulose \\
Hydrogel
\end{tabular}

\begin{abstract}
A B STRACT
Infection is the process of entering and reproducing microorganisms such as bacteria, viruses, fungi, and parasites that cause tissue injury. Some of the common types of bacteria that play a role in wound infection are Escherichia coli, Staphylococcus aureus Staphylococcus epidermis and Pseudomonas aeruginosa. The antibacterial able to inhibit bacterial growth by inhibiting cell wall biosynthesis, increasing the permeability of the bacterial cytoplasmic membrane, and interfering with the normal bacterial protein synthesis. Our specific aim of this review article is to conduct a study of nanocellulose as an antibacterial hydrogel conjugate. The method used is to summarize information from various recent journals related to nanocellulose, nanocellulose modification, nanocellulose-based hydrogels, and their application as antibacterial. Some journals from primary sources such as the PMC system (PubMed Central), National Library of Medicine (NIH), Science Direct, Elsevier, Nature, ACS Chemical Society, and several other sources. Nanocellulose consists of $\beta$-1, 4-glucose and there are three hydroxyls active at the $C_{2}, C_{3}$, and $C_{6}$ positions of the pyranose attachment. Nanocellulose can respond by the reaction of oxidation, esterification, or etherification, by adding a new functional group. Nanocellulose can become nanocellulose nanocrystals (CNC), cellulose nanofibers (NFC), and nanocellulose bacteria (BNC). Nanocellulose formulated in the form of hydrogels and combined with antibiotics will increase the effectiveness in reducing the risk of infection that is resistant to antibiotics.
\end{abstract}

\section{Introduction}

Infection is a process of entry and reproduction of microorganisms such as bacteria, fungi, viruses, and even parasites that cause tissue injury [1]. The mortality rate for children under five years in Indonesia caused by infectious diseases reaches 1-20\% every year [2]. Bacterial infections can attack various organ and respiratory systems. Some of the bacteria that commonly caused human infections are Streptococcus pneumoniae, Group A Streptococci, and Haemophilus influenzae type B [3]. Skin infections (7-10\%) are caused by Staphylococcus aureus [4], gastrointestinal infections (5\%) are frequently caused by Shigella, Escherichia coli, Campylobacter [5]. Urinary tract infections (0.7$0.9 \%$ ) are often caused by Escherichia coli, Klebsiella pneumonia, Proteus mirabilis [6].

When the body is injured, microorganisms will enter into the body, marked by damage to the tissue around the lesion and causing abscesses in the form of pus, infection, necrosis of the wound tissue, then resulting in the clotting of fibrin around the lesion and lymph vessels, and forming a wall that limits the necrosis process. . Several types of bacteria that generally play a role in wound infection are Escherichia coli, Staphylococcus aureus, Staphylococcus epidermis, and Pseudomonas aeruginosa [6-8].

Staphylococcus aureus is the bacteria that most often cause infections in humans, classified as gram-positive bacteria, often in the body of healthy people on the skin and mucosa, $20-75 \%$ are found in the upper respiratory tract, face, hands, hair, and genitals [9]. Staphylococcus aureus and staphylococcus epidermis generally cause various infections such as acne, ulcers, impetigo, and wound infections characterized by abscesses with pus [9,10]. MethicillinResistant Staphylococcus aureus (MRSA) is a type of pathogenic bacteria that often attacks 
postoperative patients with a high risk of causing death [11]. MRSA is a type of pathogenic Staphylococcus aureus that causes infection and has developed resistance to various antibiotics [12].

Due to the high case number of infections caused by bacteria hence, antibacterial (antibiotics) are needed to treat the infection. The discovering of antibiotics has continued to develop since the discovery of penicillin in 1928 [8]. The efforts to developments to find antibacterial compounds continue to develop along with the evolution experienced by bacteria so that they are resistant to several antibiotic compounds [13]. Commonly the are used synthetic antibacterial compounds are salicylates (SAL), chlorhexidine (CHX), isothiazolinone (ITZ), Octenidine (OCT), Quaternary Ammonium (QA) and thiosemicarbazone (TSC) [14].

The research regarding efficient and safe antibacterial compounds and formulations is developing an alternative to the risk of antibiotic resistance and regulate the toxicity of antibacterial drugs [15]. There are growing challenges due to antibiotic resistance researchers have studied various innovative antibacterial ingredients, including using several metal ion complexs and natural compound extracts as antibacterial agents [16]. However, these compounds kill not only pathogenic microbes but also normal cells in the human body. Somehow, that the application of the use of these materials is limited [17].

The hydrogel is an antibacterial formulation that develops using materials from natural or synthetic polymers $[17,18]$. The hydrogel was developed as an antibacterial transport medium used in infectious wounds with the characteristics of being transparent, soft, flexible, and non-irritating [19]. The hydrogel can be developed from polymer chitosan, cellulose, and some plant extracts $[19,20]$. Based on the hydrogel matrix classification and antibacterial agents, hydrogels are divided into three types: (1) Hydrogels containing metal /inorganic nanoparticles (2) Hydrogels with an antibacterial substances (3) Hydrogels with inherent antibacterial abilities. Based on the description above, in this review article, we will explain some of the latest references on how to synthesize hydrogels, the characteristics of hydrogel preparations, the hydrogel antibacterial mechanism, and cellulose modification based hydrogels as an innovative antibacterial compound.

\section{Infection-Causing Bacteria}

Infection-causing bacteria have a profound effect on public health [1-3]. The bacterial is easier infection than viruses because bacteria are fast-growing and resistant to an antimicrobial. Thus, it requires continuous development and searches to produce new antimicrobial products $[4-7,9]$.

Bacteria have an outer layer in the form of a cell wall composed of peptidoglycan. Antibacterial can interfere with the formation of the cell wall by blocking the work of enzymes, the cell wall is not formed or damaged and causes bacterial cells to lysis and die, due to the cell wall functions as a regulator of the exchange of substances from outside and into cells, and gives cell shape [21]. S, Aureus, p, aeruginosa, and $\mathrm{E}$, paecalis are common bacteria, complicating wounds, and from independent studies of clinical records relating to wounds, it was found that the survey wounds were colonized by pathogenic bacteria (Figure 1A). S. aureus is the most common bacteria found in wounds, slowing the wound healing process by $-75 \%$, making it very risky to infect wounds. Also, P. aeruginosea and E. coli with a percentage of $-17 \%$ and $-11 \%$ infected wounds (Table 1). Staphylococcus aureus usually carried by people on their skin or mucous membranes then causes skin and soft tissue infections, but also spreads easily throughout the body via the bloodstream and can cause infection of the lungs, stomach, heart valves, and almost anywhere else. The disease can be caused by damage to body cells by organisms or the body's immune response to infection [6]. 


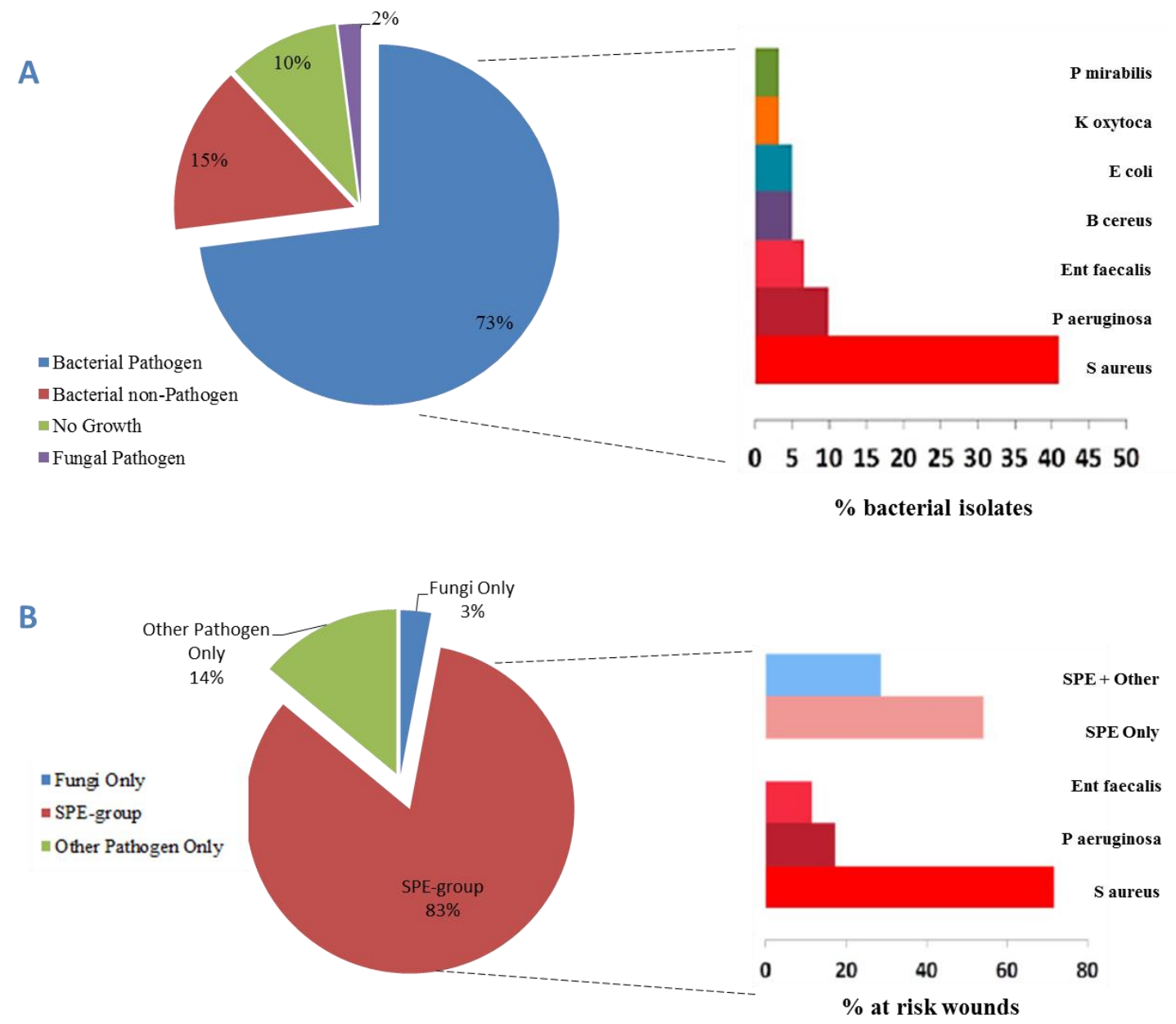

Figure 1. Data on the proportion of wounds colonized by pathogenic microbes and cases due to specific pathogens. (A) The proportion of burns colonized by pathogenic bacteria or fungi at risk of causing infection. (B) The proportion of wounds at risk of being colonized by the dominant SPE class pathogens, consisting of S. aureus, P. aeruginosa, and E. faecalis [4].

Table 1. List of bacteria studied in the development of wound biofilm models

\begin{tabular}{cccc}
\hline Species & Microbial Strains & Virulence Activity & $\begin{array}{c}\text { Reference } \\
\mathbf{s}\end{array}$ \\
\hline E. coli & $D H 5 \alpha$ & Control & {$[12,22]$} \\
S. aureus & $M S S A 475$, RN4282, USA300, & Pathogenic (except Agr-) & {$[12,23,24]$} \\
P. aeruginosa & $A g r+$, Agr & Pathogenic. & {$[12,22,24]$} \\
E. faecalis & $P A O 1$ & Pathogenic. & {$[5,6]$} \\
N, eningitides & $E 43$, E57, E68 & Infecious & {$[25,26]$} \\
\hline
\end{tabular}




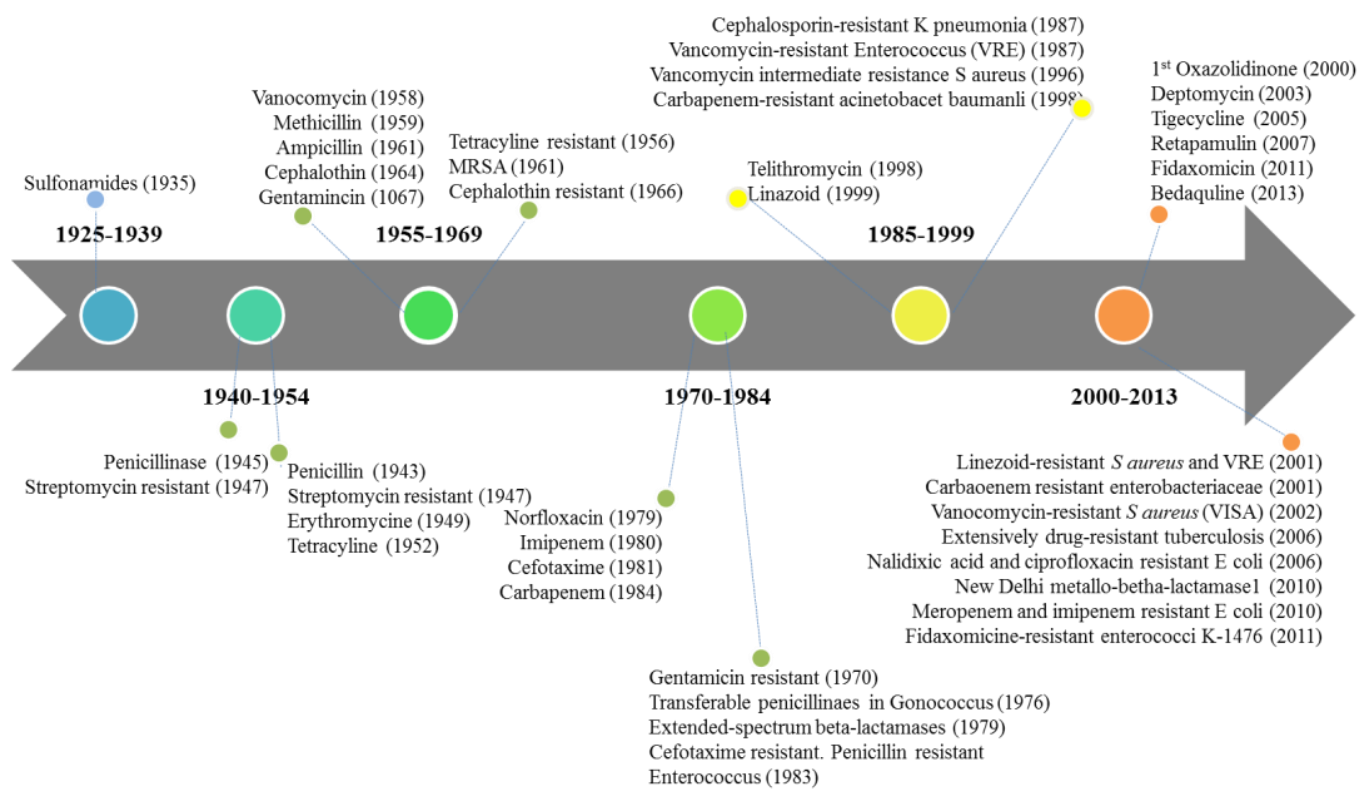

Figure 2. The history timeline of the antibacterial development and the microorganism acquisition of resistance

Bacteria can infect humans through certain organs. Neisseria meningitides commonly infect the meninges by covering of the central nervous system, causing meningitis, and can also infect the lungs, causing pneumonia. Moreover, bacterial infection causes systemic inflammatory response syndrome (SIRS), is an inflammatory response to infection, by the release of large amounts of cytokines, cytokine storms, and there are signs of infection and early signs of hemodynamic instability (Daron and Gorbach, 2008).

\section{Antibacterial Compound}

The evolution of bacteria leads to efforts to develop technology and knowledge to find antibacterial compounds that can work optimally [28]. Generall the antibacterial mechanism work by damaging cell walls, changing membrane permeability, interfering of protein and nucleic acid synthesis, and inhibiting enzyme action $[25,26,28]$. The discovery of antibiotics has continued to develop since 1928, the discovered penicillin and has been widely used as an antibacteria [8]. The efforts to discover an antibacterial compound continue to develop along with the bacteria, resistant to several antibiotic compounds [13]. In inhibition of bacterial cell protein synthesis, generally antibacterial, will cause misread the code in mRNA by tRNA (translation and transcription barrier of genetic material) such as aminoglycosides, also inhibit following the same inhibition pathway. Generally, antibacterial compounds will bind to one of the components that play a role in the synthesis stage [29]. The clinical use of synthetic antibacterials has disadvantages such as high toxicity, high cost, and their use often leads to the emergence of resistance. Staphylococcus epidermis bacteria have been resistant to penicillin and methicillin antibiotics [30]. Recently, efforts and development for alternative antibacterials, by utilizing natural ingredients (secondary metabolites) as traditional medicines (ethnobotany) instead of synthetic antibiotics [31].

The antibacterial mechanism is influenced by the content of secondary metabolite compounds as active compounds. Tannin compounds, as antibacterial can able to inhibit bacterial cell synthesis by topoisomerase inhibition [32]. Moreover, tannins has cell wall polypeptides target, and the formation of the cell walls does not complete, then causes bacterial cells to become lysed due to osmotic or physical pressure so that the bacterial cells will die [33]. The mechanism of antibacterial activity of flavonoids by inhibiting nucleic acid synthesis, cell membrane permeability function, and energy metabolism inhibition [34]. 
Flavonoids inhibit nucleic acid synthesis, which is $A$ and $B$ rings play an important role in the hydrogen bonding process by inhibiting the formation of DNA and RNA. Flavonoids also cause to damage the permeability of bacterial cell walls, microsomes, and liposomes [34]. Flavonoids can form a complex compound from extracellular and dissolved proteins counterparts, the cell membrane will be damaged, and intracellular compounds will come out [34,35]. Meanwhile, its can inhibiting energy metabolism, bacteria unable to use oxygen uptake, then preventing the energy formation in the cytoplasmic membrane, inhibiting the bacteria motility, which plays a role in antimicrobial activity and extracellular proteins [36]. Alkaloid compounds have an inhibitory mechanism by damaging the peptidoglycan constituent components in bacterial cells that the cell wall layer is not fully formed and causes cell death [34,37].

Saponin antibacterial activity can reduce the cell walls' surface tension and increase surface permeability, cell leakage, and intracellular compounds being released [35]. The terpenoid mechanism is through the process of breaking down the membrane by lipophilic components so that it damages the bacterial cell membrane [21,38]. The antibacterial mechanism of phenol compounds in killing microorganisms is by denaturing cell proteins, the hydrogen bonds formed between phenols and proteins causing the protein structure to be damaged and affecting the permeability of the cell wall and cytoplasmic membrane, which is disturbed which can cause unbalanced macromolecules and cell ions, and finally the cells become lysis.

A semicrystalline polysaccharide of nanocellulose-based antibacterial cellulose exists in nature in the fibers form, ranging from
0.5 to $0.8 \mathrm{~mm}$ [39]. Cellulose composes $\beta$-Dglucopyranose, which is connected by $1-4-\beta-$ glycosidic bonds. The compound chains come together and form basic fibrils consisting of crystalline and amorphous domains. The structure of cellulose allows it to break down into nanocellulose, which are produced using mechanical-based methods, by bacteria into crystal nanocellulose (CNC), bacterial nanocellulose (BNC), and cellulose nanofibers (CNF) [40]. Previous studies have found that nanocellulose untilizing has several advantages for cellular culture, medicinal excipients, drug candidate administration; cellulose immobilization, and either enzymes and proteins recognition. Moreover, it also the macroscopic biomaterial level (Blood vessels, soft tissue substitutes, skin, bone tissue repair agents, and antimicrobial agents).

The functional modification of nanocellulose has high potential biomedical applications of nanocellulose modified $[13,41]$. Furthermore, nanocellulose is used as drug delivery by adding to the content of antibiotic compounds. These antibiotic compounds are used to strengthen the antimicrobial activity of cellulosic materials such as polymyxin B, ampicillin, tetracycline- $\mathrm{HCl}$, gentamycin, ceftriaxone, and chloromycetin. Nanocellulose formulated in the form of a hydrogel and combined with antibiotics will increase the effectiveness in reducing the risk of infection that is resistant to antibiotics. In addition to nanocellulose, several polymer compounds that are widely used are chitosan, an antimicrobial polymer that shows good antibacterial activity in either Bacillus cereus and Salmonella typhimurium. The presence of chitosan biofilm of the nano-fiber chitosan (NFC) showed an antibacterial activity against Escherichia coli and Staphylococcus aureus. 


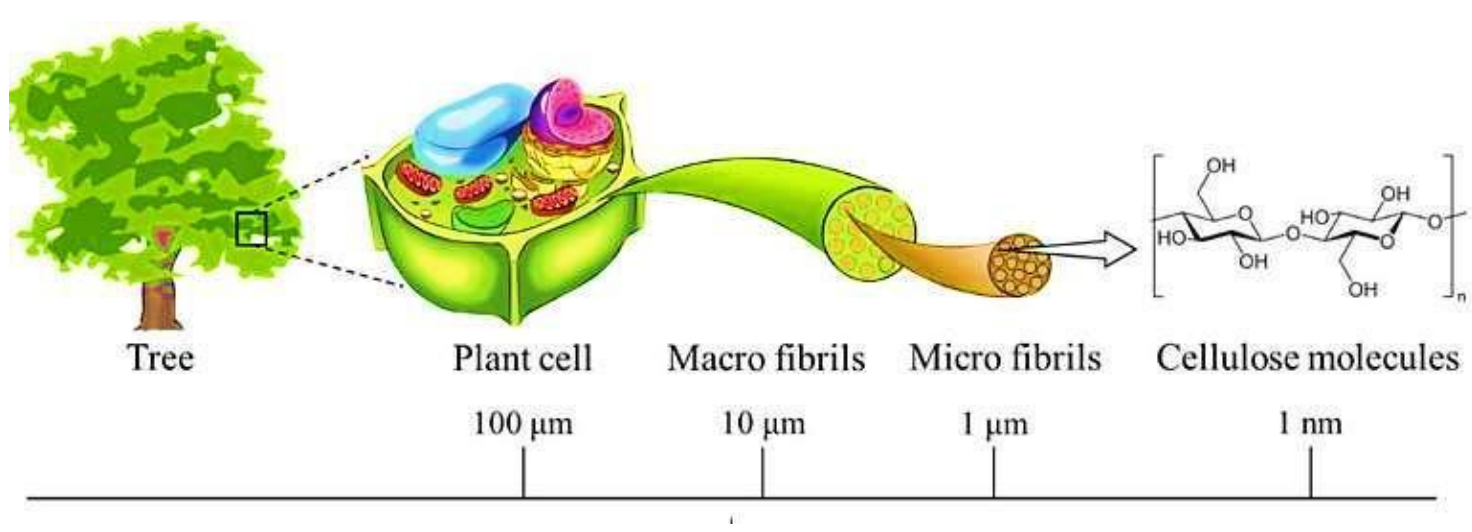

Figure 3. Cellulose found in plants or trees has a hierarchical structure from the meter to the nanometer scale [26].

The development of nanocellulose-based antimicrobials has attracted a lot of attention because of their unique characteristics and potential for widespread use. The nanocellulose was using for wound healing, drug delivery, and other advanced materials. Nanocellulosebased antimicrobial agents are an abundantly source, biodegradable, and much more easily be prepared. The method in modifying nanocellulose as an antibacterial material is carried out $[1,6,9]$ by modifying the surface of the nanocellulose. Nanocellulose consists of $\beta$ 1,4-glucose with three hydroxyls active group at the $C_{2}, C_{3}$, and $C_{6}$ positions of the co-pyranose glu-ring. Nanocellulose can modify through oxidation, esterification, or etherification reaction, which will introduce new functional groups. Functional groups contain antimicrobial properties include the quaternary aldehyde and ammonium groups, that shows good antibacterial activity and biocompatibility. Besides, in combination with nanomaterials, inorganic nanoparticles are also widely used based on nanocellulose as an antimicrobial material, such as precious metal nanoparticles and metal oxide nanoparticles. The minimal inhibitory concentration (MIC) of nanocellulose-based materials containing inorganic nanoparticles is much lower than that of single metal or metal oxide nanoparticles, which are beneficial to humans, environment, and health [24-26].

\section{Modification of Nanocellulose}

There are various bio-nano composites, which are produced based on CNC as nanofillers and natural polymer matrices, protein, gluten, chitosan, gelatin, cyclodextrins, maltodextrins, starch, alginate, natural rubber, xanthine, and cellulose derivatives CMC (carboxymethyl cellulose), hydroxypropyl cellulose, regenerated cellulose, and cellulose diacetate). Modifications have been to optimize nanocellulose, such as surface modification. The modifications of nanocellulose can be carried out by oxidation of hydroxyl using TEMPOoxidation or ammonium persulfate [41]. Modification of nanocellulose to 2,3-dialdehyde NFC (DANFC) using periodate sodium and DANFC has antibacterial activity against both of multidrug-reistant (MDR) of S. aureus and $S$. aureus increases in proportion to the increase in aldehyde content [26]. 


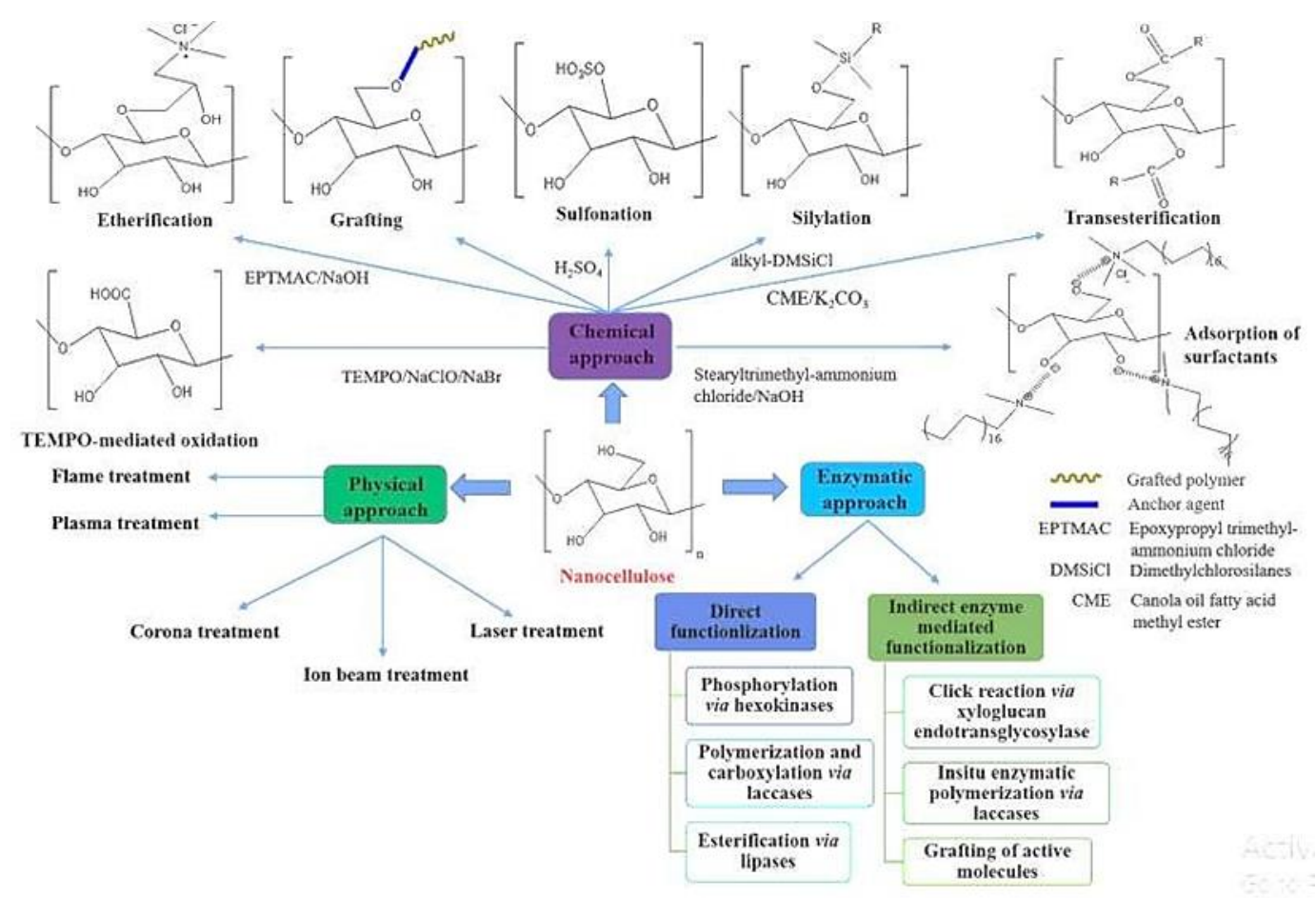

Figure 4. Schematic representation of the nanocellulose surface modification route [26].

Recently, nanocellulose-based antibacterial has been developed by grafting quaternary ammonium compounds. Which are the most widely used antimicrobial agents due to their antibacterial properties, such as low toxicity, and environmental compatibility. The cationic phosphorous on the NCC surface was modified via the $\mathrm{Cu}(\mathrm{I})$-catalyzed Huisgen-MeldalSharpless reaction, capable to inactivated $S$. aureus, and Mycobacterium smegmatis, although with little activity against $E$. coli.

\section{Hydrogel as an Antimicrobial Agent}

The hydrogel is a polymer with 3dimensional network can absorb and bind water molecules with very high ability in a relatively short time and can maintain a swelling state at a certain pressure [24,42], due to the hydrogel has hydrophilic groups, able to absorb fluids and retain a number of fluids, and release them under certain conditions. Moreover, the hydrogel absorb a large amounts of water molecules and has a good biocompatibility, so the hydrogel can be used as a wound covering, release system medicine, cosmetics, medicinal shell, and agriculture. Instead of natural hydrogels, it also can produced by synthetic polymers, polyvinyl pyrrolidine, from polyacrylic acid, as well as natural polymers such as chitosan, cellulose, carrageenan, and alginate [19]. The hydrogel then applied as a drug delivery, the hydrogel network can control the release system for small molecule encapsulates so that it can be used as an antimicrobial agent, antibiotics, metal compounds, and other organic compounds [43]. The hydrogel that has been developed is a hydrogel with a polymer base, without the addition of drugs, the hydrogel is developed with the addition of banana sap to accelerate the wound healing process. The PEO-PEGDMA hydrogel film with the addition of banana sap was proven to be able to increase the acceleration of the speed of wound healing with the optimal percentage of wound healing occurring at a $15 \%$ concentration of PEOPEGDMA-Banana Gum which can be inserted into the hydrogel tissue which acts as a matrix $[20,44]$.

The hydrogel can be used as a wound cover made from PVA chitosan and starch, with the addition of smoke. Coconut shell liquid and vitamin K [19] which can heal irritated wounds in test animals can heal on day 10. Somehow, it also can incorporate Ag NPs into hydrogel matriks by semi-interpenetrating polymer fingers [16]. Ag-hydrogel nanocomposite has been used as wound healing, wound dressings, for biomedical applications, and water purification. Chitin-Chitosan have antibacterial 
activity and metal-binding shifts. The hydrogels can be made by utilizing antibacterial compounds from natural ingredients as active compounds, such as banana sap, seaweed, and betel leaf. The content of banana sap which functions as an antibiotic, pain reliever, and can stimulate skin cell growth, is used as a basic ingredient in the manufacture of hydrogels as antibacterial agents. The application of hydrogel can inhibit wound infection so that it can be categorized as antibacterial [45]. The content of secondary metabolites of Tapak Kuda leaves such as flavonoids, steroids, alkaloids, saponins, terpenoids, tannins, and anthraquinones have been formulated antibacterial gel [46]. Tagetas erecta leaves contain flavonoid and phenolic as bioactive compounds, that have antibacterial activity [13,19,21,24-26,28-33,35-41,43-47]. In addition, it is also known that the Ceremai plant (Phyllanthus acidus (L.) is useful as an antibacterial which plays a role in preventing infection [46]. Moreover, plant seeds contain phytochemical compounds, flavonoids as antibacterial, the ethyl acetate extract of Ceremai leaves has an effective antibacterial activity using a concentration of $8 \%$ [23].

Hydrogel production produced by the process of Fteezing Thawing, and gamma-ray irradiation $[13,25]$. The hydrogel is formed by macromolecular cross-linking to produce specific 3-dimensional structures with precise chemical and mechanical properties. Previous studies reported that hydrogels obtain by crosslinking of Pegagan leaves extract with N'Nmethylene bis-acrylamide [38]. In addition, hydrogels can also take advantage of rice straw which contains sufficient cellulose for the manufacture of hydrogels. Hydrogels are synthesized using tea plants, by utilizing cellulose content which is carried out using the cross-linking method with a mixture of aluminum sulfate $[21,37,38]$.

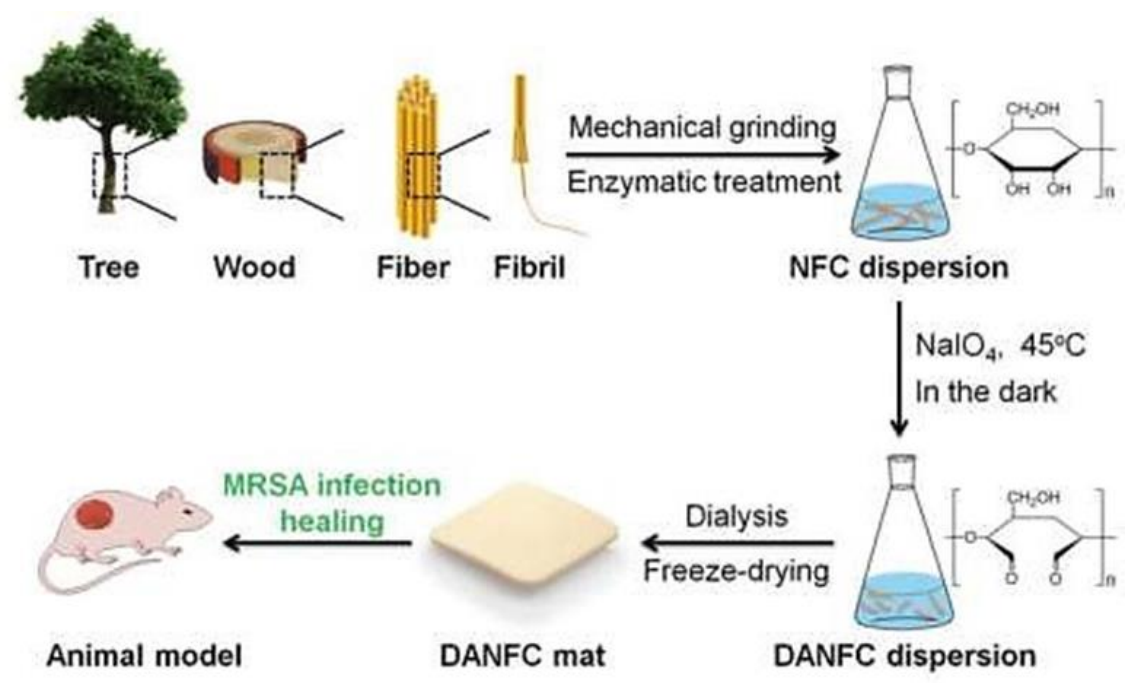

Figure 5. Schematic of the DANFC experimental process and the effect of wound cover on the Mouse Model [48]

The hydrogel synthesis method is the hydrothermal method, using Na-CMC SelfCross-linking reaction on an unstable active hydroxyl group on $\mathrm{NaCMC}$, the addition of chitosan can reduce the occurrence of SelfCrosslinking so that it can strengthen the hydrogel [49]. The manufacture of hydrogel based on natural polymers, pectin, and gelatin. These two materials, combined using the crosslinking by adding citric acid as a cross-linking agent and affects the hydogel properties of the hydrogel material. The hydrogel made in the form of a film will produce the highest thickness, Swelling Ratio, and degree of substitution at a concentration of $10 \%$ citric acid. While the highest gel fraction was produced by hydrogel with $20 \%$ of citric acid.

\section{Hydrogel characterization}

Characterization of the physical and chemical properties of the hydrogel was carried out to determine the raw material standards to suit the needs [25]. Viscosity characterization to determine the level of solution viscosity, gel strength, water content, ash content to 
determine mineral content and determine the ash content that is insoluble in acid, measure the gel fraction, swelling ratio, water vapor transmission speed, and mechanical properties, determine the chemical structure and the morphology can use FTIR and SEM, to prove the acceleration of wound healing speed was analyzed using in vivo test $[1,5,7]$. SEM test to analyze the surface, shape, texture, and size of the membrane from the hydrogel as a cover for burns, the presence of a pore on the hydrogel shows that the membrane covering the hydrogel wound contains the active compound [19].

The swelling ratio is the main parameter of the hydrogel to determine hydrogel weight in the water-absorbing state [20]. Preparation of hydrogels with a combination of Galactomannan polymer from guar gum and PVA. PVA has a structure that can interact with hydrogen bonds, so that it can bind insoluble compounds and make them easily soluble and hydroscopic so that they can absorb water, form a good gel, and have high adhesion [50]. For example, the Hydrogel formula for Wound Dressings Using a Combination of Galactomannan and PVP Polymers [42].

The results of the physical characteristics of the preparations were the diameter, thickness, and folding power of the preparations. Based on table 4, the hydrogel thickness test shows that formula three is following the specifications, 0.4-0.7 mm, but formulas $1,2,4$, and 5 have very low thickness [42].

\section{Hydrogel contains Antibiotics}

The hydrogel is able to selectively kill bacteria, so it can be used as an effective antiinfection in the right dose [44]. The addition of other compounds to the hydrogel matrix aims to build hydrogel composites that can act as antimicrobials, for example, the addition of trisodium phosphate, acidified sodium chloride which is incorporated into starch as an antimicrobial [51].

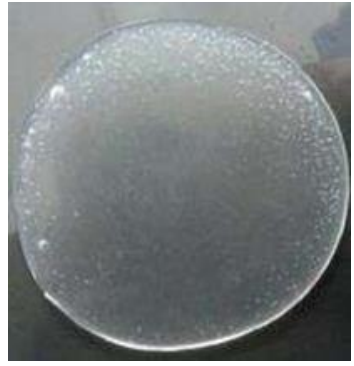

Figure 6. Hydrogel formula for galactomannan polymer wound dressings [42]

Furthermore, several modifications were made to increase the hydrogel antibacterial activity by adding antibiotic or metal compounds. AgNP-modified Nanocomposite of Hydrogel has good antibacterial activity against both gram positive and negative bacteria. The modification uses the biopolymer sodium alginate as the main component [52]. In addition to modifications using metal elements, several modifications have also been made to the surface of the nanocellulose. Cellulose nanocrystals (CNCs) of surface modified bears with various functional groups such as $\mathrm{SO}_{4}$, esters after sulfuric acid isolation, $\mathrm{OH}^{-}$after enzymatic or hydrochloric acid treatment, and $\mathrm{COOH}$ after oxidative isolation in the presence of 2,2,6,6-tetramethyl- piperidinyl-1 -oxyl (TEMPO) radicals [53].

Hydrogel as an antimicrobial can quickly prevent infection, make wounds heal faster [54], smooth, easy to use, able to keep skin moist, have an attractive appearance, do not irritate the skin, and last longer in wound tissue [55]. In addition, the hydrogel functions to keep the wound environment moist softens, and destroys the necrotic tissue without damaging healthy tissue, which is then absorbed into the gel structure and removed with the dressing (natural autolytic debridement) [56].

The use of hydrogel as an antibacterial material needs to be continuously developed so that the remaining matrix that remains after the drug is released can be removed [43]. Chitosanbased hydrogel with honey and gelatin has weaknesses in water absorption and modulus young so that it is not good for dressing wounds for a long time, high chitosan viscosity and poor honey dilution can cause losses in the compatibility of hydrogel components $[57,58]$. 


\section{Acknowledgments}

Thank you to the Director General of Belmawa, Kemendikbud DIKTI for the 2019 PKM research grant.

\section{Conclusion}

Our finding in this article review that infection can occur, one of which is caused by the presence of bacteria and viruses. The discovery and development of antibacterial compounds have been carried out with various innovations such as being developed in the form of a hydrogel. Nanocellulose is one of the ingredients that can be used as an antibacterial hydrogel either directly with nanocellulose or modified with other materials. Nanocellulose can be modified into nanocrystal nanocellulose (CNC), cellulose nanofibers (NFC), and bacterial nanocellulose (BNC). Nanocellulose is formulated in the form of a hydrogel and combined with antibiotics will increase its effectiveness in reducing the risk of infection that is resistant to antibiotics.

\section{References}

1. Kumakauw, V.V.; Simbala, H.E.I.; Mansauda, K.L.R.,; Aktivitas Antibakteri Ekstrak Etanol Daun Sesewanua (Clerodendron Squamatum Vahl.) terhadap Bakteri Staphylococcus aureus Escherichia coli dan Salmonella typhi. Jurnal MIPA, 2020, 9(2), pp.86-90.

2. Ki, V.; Rotstein, C. Bacterial Skin and Soft Tissue Infections in Adults: A Review of Their Epidemiology, Pathogenesis, Diagnosis, Treatment and Site of Care. Can J Infect Dis Med Microbiol 2008, 19, 173-184.

3. Kronman, M.P.; Zhou, C.; Mangione-Smith, R. Bacterial Prevalence and Antimicrobial Prescribing Trends for Acute Respiratory Tract Infections. Pediatrics 2014, 134, e956965, doi:10.1542/peds.2014-0605.

4. Marshall, S.E.; Hong, S.-H.; Thet, N.T.; Jenkins, A.T.A. Effect of Lipid and Fatty Acid Composition of Phospholipid Vesicles on Long-Term Stability and Their Response to Staphylococcus Aureus and Pseudomonas Aeruginosa Supernatants. Langmuir 2013, 29, 6989-6995, doi:10.1021/la401679u.

5. Flores-Mireles, A.L.; Walker, J.N.; Caparon,
M.; Hultgren, S.J. Urinary Tract Infections: Epidemiology, Mechanisms of Infection and Treatment Options. Nat Rev Microbiol 2015, 13, 269-284, doi:10.1038/nrmicro3432.

6. Ningsih, A.P.; Agustien, A., Uji aktivitas antibakteri ekstrak kental tanaman pisang kepok kuning (Musa paradisiaca Linn.) terhadap Staphylococcus aureus dan Escherichia coli. Jurnal Biologi UNAND, 2013. 2(3).

7. Razak, A.; Djamal, A.; Revilla, G. Uji Daya Hambat Air Perasan Buah Jeruk Nipis (Citrus Aurantifolia s.) Terhadap Pertumbuhan Bakteri Staphylococcus Aureus Secara In Vitro. Jurnal Kesehatan Andalas 2013, 2, 05-08.

8. Tan, S.; Tatsumura, Y. Alexander Fleming (1881-1955): Discoverer of Penicillin. smedj 2015, 56, 366-367, doi:10.11622/smedj.2015105.

9. Turnip, N.U.M.B.; Nurdianti; Dwicahya, C.A. Uji Efektivitas Antibakteri Sediaan Salep dari Ekstrak Daun Kersen (Muntingia Calabura L.) Terhadap bakteri Staphylococcus Aureus. JURNAL FARMASIMED (JFM) 2020, 2, 85-90, doi:10.35451/jfm.v2i2.373.

10. Dewi, I.P.; Orde, I.M.; Verawaty, V. EFEKTIVITAS GEL EKSTRAK ETANOL BAWANG PUTIH (Allium Sativum L.) TERHADAP BAKTERI Staphylococcus Aureus. Jurnal Riset Kefarmasian Indonesia 2020, 2, 105-112, doi:10.33759/jrki.v2i2.84.

11. Nursidika, P.; Saptarini, O.; Rafiqua, N. Aktivitas Antimikrob Fraksi Ekstrak Etanol Buah Pinang (Areca Catechu L) Pada Bakteri Methicillin Resistant Staphylococcus Aureus. Majalah Kedokteran Bandung 2014, 46, 94-99.

12. Erikawati, D.; Santosaningsih, D.; Santoso, S. Tingginya Prevalensi MRSA pada Isolat Klinik Periode 2010- 2014 di RSUD Dr. Saiful Anwar Malang, Indonesia. Jurnal Kedokteran Brawijaya 2016, 29, 149-156, doi:10.21776/ub.jkb.2016.029.02.9.

13. Yuliani, R.; Prasetyo, M.N.; Liberitera, S. Aktivitas Antibakteri Beberapa Ekstrak Tanaman Terhadap Escherichia Coli Resisten Antibiotik. Proceeding of The URECOL 2019, 80-87.

14. Handbook of Nanomaterials Properties; 
Bhushan, B., Luo, D., Schricker, S.R., Sigmund, W., Zauscher, S., Eds.; Springer Berlin Heidelberg: Berlin, Heidelberg, 2014; ISBN 978-3-642-31106-2.

15. Sekarini, A.A.A.D.; Krissanti, I.; Syamsunarno, M.R.A.A. Efektivitas Antibakteri Senyawa Kurkumin Terhadap Foodborne Bacteria: Tinjauan Curcuma Longa Untuk Mengatasi Resistensi Antibiotik. Jurnal Sains dan Kesehatan 2020, 2, 538-547.

16. Liu, L.; Feng, X.; Pei, Y.; Wang, J.; Ding, J.; Chen, L. $\alpha$-Cyclodextrin ConcentrationControlled Thermo-Sensitive Supramolecular Hydrogels. Mater Sci Eng C Mater Biol Appl 2018, 82, 25-28, doi:10.1016/j.msec.2017.08.045.

17. Wei, L.; Chen, J.; Zhao, S.; Ding, J.; Chen, X. Thermo-Sensitive Polypeptide Hydrogel for Locally Sequential Delivery of TwoPronged Antitumor Drugs. Acta Biomater 2017, 58, 44-53, doi:10.1016/j.actbio.2017.05.053.

18. Kamoun, E.A.; Kenawy, E.-R.S.; Chen, X. A Review on Polymeric Hydrogel Membranes for Wound Dressing Applications: PVA-Based Hydrogel Dressings. J Adv Res 2017, 8, 217-233, doi:10.1016/j.jare.2017.01.005.

19. Saputra, A.A.S.; Dewi, T.; Ramadhani, E.K.; Ibrahim, N.; Wibisono, G. Penutup luka hydrogel berbasis polivinil alkohol (PVA), kitosan, pati dengan penambahan asap cair dan vitamin k. Wound Dressing of Hydrogel Based on Polyvinyl-Alcohol (PVA)/Chitosan/Starch Combined Liquid Smoke and Vitamin K 2020.

20. Sunardi, S. Hidrogel berbasis selulosa purun tikus (Eleocharis dulcis) tercangkok akrilamida dengan proses pretreatment menggunakan larutan urea/sodium hidroksida. Prosiding Seminar Nasional Lingkungan Lahan Basah 2018, 3.

21. Zengin, H.; Baysal, A.H. Antibacterial and Antioxidant Activity of Essential Oil Terpenes against Pathogenic and SpoilageForming Bacteria and Cell StructureActivity Relationships Evaluated by SEM Microscopy. Molecules 2014, 19, 1777317798, doi:10.3390/molecules191117773.

22. Fletcher, S.M.; McLaws, M.-L.; Ellis, J.T.
Prevalence of Gastrointestinal Pathogens in Developed and Developing Countries: Systematic Review and Meta-Analysis. J Public Health Res 2013, 2, 42-53, doi:10.4081/jphr.2013.e9.

23. Dewi, L.A.P. Pembuatan Gel Ekstrak Daun Pepaya Dengan Variasi Penambahan Hydroxypropyl Methyl Cellulose. Politeknik Negeri Sriwijaya, 2016.

24. Edy, H.J. Formulasi dan Uji Sterilitas Hidrogel Herbal Ekstrak Etanol Daun Tagetes Erecta L. PHARMACON 2016, 5, doi:10.35799/pha.5.2016.12163.

25. Fransiska, D.; Reynaldi, A. Karakteristik Hidrogel Dari Iota Karaginan Dan PVA (Poly-Vinyl Alcohol) Dengan Metode Freezing-Thawing Cycle. Jambura Fish Processing Journal 2020, 1, 24-34, doi:10.37905/jfpj.v1i1.4503.

26. Trache, D.; Tarchoun, A.F.; Derradji, M.; Hamidon, T.S.; Masruchin, N.; Brosse, N.; Hussin, M.H. Nanocellulose: From Fundamentals to Advanced Applications. Front. Chem. 2020, 8, doi:10.3389/fchem.2020.00392.

27. Li, J.; Cha, R.; Mou, K.; Zhao, X.; Long, K.; Luo, H.; Zhou, F.; Jiang, X. NanocelluloseBased Antibacterial Materials. Adv Healthc Mater 2018, 7, e1800334, doi:10.1002/adhm.201800334.

28. Paju, N.; Yamlean, P.V.; Kojong, N.; Uji efektivitas salep ekstrak daun binahong (Anredera cordifolia (Ten.) Steenis) pada kelinci (Oryctolagus cuniculus) yang terinfeksi bakteri Staphylococcus aureus. Pharmacon. 2013, 1;2(1).

29. Riski, D.G.; Maulana, R.G.R.; Permana, E.; Lestari, I.; Tarigan, I.L. Profile Analysis of Fatty Acids of Tengkawang (Shorea Sumatrana) Oil Using GC-MS and Antibacterial Activity. Indonesian Journal of Chemical Research 2020, 8, 114-119, doi:10.30598//ijcr.2020.8-dgr.

30. Pradhan, J.; Das, S.; Das, B. Antibacterial Activity of Freshwater Microalgae: A Review. 2014, 8, 809-818, doi:10.5897/AJPP2013.0002.

31. Anggraeni, V.J.; Wahyu, T.S.; Kusriani, H.; Kurnia, D. Aktivitas Antibakteri Ekstrak Mikroalga Thalassiosira Sp Terhadap Bakteri Staphylococcus Aureus, 
Staphylococcus Epidermidis Dan Propionibacterium Acne. Jurnal Kimia Riset 2019, 4, 62-73, doi:10.20473/jkr.v4i1.13314.

32. Ashok*, P.K.; Upadhyaya, K. Tannins Are Astringent. J Pharmacogn Phytochem 2012, 1, 45-50.

33. Fratiwi, Y. THE POTENTIAL OF GUAVA LEAF (Psidium Guajava L.) FOR DIARRHEA. Jurnal Majority 2015, 4.

34. Nuralifah, N.; Armadany, F.; Parawansah, P.; Pratiwi, A. Uji Aktivitas Antibakteri Sediaan Krim Anti Jerawat Ekstrak Etanol Terpurifikasi Daun Sirih (Piper Betle L.) Dengan Basis Vanishing Cream Terhadap Propionibacterium Acne. Pharmauho: Jurnal Farmasi, Sains, dan Kesehatan 2019, 4, doi:10.33772/pharmauho.v4i2.6261.

35. Puspita, W.; Awaliah, P.D. In Vitro Antibacterial Activity Of Lime Fruit Juice (Citrus Aurentifolia) On Staphylococcus Aereus Bacteria. 2020, 8.

36. Cushnie, T.; Lamb, A. Antimicrobial Activity of Flavonoids. International journal of antimicrobial agents 2005, 26, 343-56, doi:10.1016/j.ijantimicag.2005.09.002.

37. Chairani, A.; Harfiani, E. Efektivitas Getah Jarak Sebagai Antiseptik Terhadap Pertumbuhan Staphylococcus Aureus, Escherichia Colidan Candida Sp. Secara In Vitro. Jurnal Kedokteran Universitas Lampung 2018, 2, 84-92, doi:10.23960/jk.

38. Mahizan, N.A.; Yang, S.-K.; Moo, C.-L.; Song, A.A.-L.; Chong, C.-M.; Chong, C.-W.; Abushelaibi, A.; Lim, S.-H.E.; Lai, K.-S. Terpene Derivatives as a Potential Agent against Antimicrobial Resistance (AMR) Pathogens. Molecules 2019, 24, doi:10.3390/molecules24142631.

39. Klemm, D.; Kramer, F.; Moritz, S.; Lindström, T.; Ankerfors, M.; Gray, D.; Dorris, A. Nanocelluloses: A New Family of Nature-Based Materials. Angewandte Chemie (International ed. in English) 2011, 50, 5438-66, doi:10.1002/anie.201001273.

40. Lewandowska-Łańcucka, J.; Karewicz, A.; Wolski, K.; Zapotoczny, S. Surface Functionalization of Nanocellulose-Based Hydrogels. In Cellulose-Based Superabsorbent Hydrogels; Mondal, Md.I.H., Ed.; Polymers and Polymeric Composites: A Reference Series; Springer International Publishing:
Cham, 2019; pp. 705-733 ISBN 978-3-31977830-3.

41. Boufi, S.; González, I.; Delgado-Aguilar, M.; Tarrès, Q.; Pèlach, M.À.; Mutjé, P. Nanofibrillated Cellulose as an Additive in Papermaking Process: A Review. Carbohydrate Polymers 2016, 154, 151-166, doi:10.1016/j.carbpol.2016.07.117.

42. Rahayuningdyah, D. W., Pengembangan Formula Hidrogel Balutan Luka Menggunakan Kombinasi Polimer Galaktomanan dan PVP. Pharmaceutical Journal of Indonesia, 2020 5, 2,117-122.

43. Chauhan, M.; Patel, S.; Patel, S.K. A Concise Review on Sustained Drug Delivery System and Its Opportunities. undefined 2012.

44. Peng, N.; Zhang, X.; Xu, H.; Liu, Y. Polymeric Hydrogels with Antimicrobial Activity-A Review of Their Progress. BJSTR 2019, 23, 17810-17823, doi:10.26717/BJSTR.2019.23.003973.

45. Julianto, E.; Sudiarto Julianto E, Sudiarto S. Hidrogel Ekstrak Bonggol Pisang, Rumput Laut Dan Daun Sirih Untuk Luka Bakar. MNJ (Mahakam Nursing Journal). 2018 Nov 17;2(4):151-8.

46. Saraung, V. Pengaruh Variasi Babis Karbopol Dan Hpmc Pada Formulasi Gel Ekstrak Etanol Daun Tapak Kuda (Ipomoea Pes-Caprae (L.) R. BR. dan Uji Aktivitas Antibakteri Terhadap Staphylococcus Aureus. PHARMACON 2018, 7, doi:10.35799/pha.7.2018.20452.

47. Edy, H.J.; Marchaban, M.; Wahyuono, S.; Nugroho, A.E. Pengujian Aktivitas Antibakteri Hidrogel Ekstrak Etanol Daun Tagetes Erecta L. Jurnal MIPA 2019, 8, 9698, doi:10.35799/jmuo.8.3.2019.25582.

48. Mou, K.; Li, J.; Wang, Y.; Cha, R.; Jiang, X. 2,3-Dialdehyde Nanofibrillated Cellulose as a Potential Material for the Treatment of MRSA Infection. J. Mater. Chem. B 2017, 5, 7876-7884, doi:10.1039/C7TB01857F.

49. Adi, S.H.; Heryani, N. Sintesis dan optimasi hidrogel berbasis sodium carboxymethyl cellulose dan chitosan dengan metode hidrotermal. j. widyariset 2020, 5, 1, doi:10.14203/widyariset.5.1.2019.1-10.

50. Hamzah, N. Teknik Sintesis Povidon. Jurnal farmasi UIN Alauddin Makassar 2018, 5, 205224, doi:10.24252/jurfar.v5i3.4358. 
51. Mehyar, G.F.; Liu, Z.; Han, J.H. Dynamics of Antimicrobial Hydrogels in Physiological Saline. Carbohydrate Polymers 2008, 74, 92-98, doi:10.1016/j.carbpol.2008.01.023.

52. Alexandrescu, L.; Syverud, K.; Gatti, A.; Chinga Carrasco, G. Cytotoxicity Tests of Cellulose Nanofibril-Based Structures. Cellulose 2013, 20, doi:10.1007/s10570-0139948-9.

53. Ashadi, R.W. SINTESIS Biodegradable Hydrogel Dari Amorpophallus Oncophyllus. Jurnal Pertanian 2017, 1, 9-16, doi:10.30997/jp.v1i1.549.

54. Siskaningrum, A. Efektifitas Hidrogel Binahong (Anredera Cordifolia (Ten.) Steenis) Terhadap Luas Luka Pada Tikus Hiperglikemia (Rattus Norvegicus) Galur Wistar. Jurnal Keperawatan 2019, 17, doi:10.35874/jkp.v17i1.470.

55. Hasyim, N. K.; Pare, L.; Junaid, I,; Kurniati. A.; "Formulasi dan UJI efektivitas gel luka bakar ekstrak daun cocor bebek (Kalanchoe pinnata L.) pada kelinci (Oryctolagus cuniculus)." Majalah Farmasi dan Farmakologi. 2012 16, no. 2 : 89-94.

56. Mustamu, A. C.; Mustamu, H. L.; Hasim, N. H.; Peningkatan Pengetahuan \& Skill Dalam Merawat Luka. Jurnal Pengabdian Masyarakat Sasambo, 2020, 1(2), 103-109.

57. Wang, K.; Nune, K.C.; Misra, R.D.K. The Functional Response of Alginate-GelatinNanocrystalline Cellulose Injectable Hydrogels toward Delivery of Cells and Bioactive Molecules. Acta Biomaterialia 2016, 36 , 143-151, doi:10.1016/j.actbio.2016.03.016.

58. Wang, S.; Sun, J.; Jia, Y.; Yang, L.; Wang, N.; Xianyu, Y.; Chen, W.; Li, X.; Cha, R.; Jiang, $X$. Nanocrystalline Cellulose-Assisted Generation of Silver Nanoparticles for Nonenzymatic Glucose Detection and Antibacterial Agent. Biomacromolecules 2016, 2472-2478, doi:10.1021/acs.biomac.6b00642.

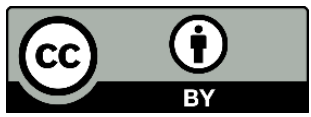

(C) 2021 by the authors. Licensee Fullerene Journal Of Chem. This article is an open access article distributed under the terms and conditions of the Creative Commons Attribution (CC BY) license (http://creativecommons.org/licenses/by/4.0/). 